УДК 37.015.31:17.022

DOI:

Галина Білавич, доктор педагогічних наук, професор кафедри педагогіки початкової освіти Прикарпатського національний університету імені Василя Стефаника

Ірина Дідух, кандидат педагогічних наук, доиент,

дочент кафедри сочіальної педагогіки та соціальної роботи Прикарпатського національний університету імені Василя Стефаника Олег Довгий, кандидат фізико-математичних наук, доиент, доиент кафедри педагогіки початкової освіти Прикарпатського національний університету імені Василя Стефаника Ірина Данилів, студентка Прикарпатського національний університету імені Василя Стефаника

\title{
КАЗКИ ТА ОПОВІДАННЯ ВАСИЛЯ СУХОМЛИНСЬКОГО ЯК ЧИННИК МОРАЛЬНОГО ВИХОВАННЯ ОСОБИСТОСТІ ДИТИНИ
}

Стаття присвячена літературній спадщині Василя Сухомлинського. Автори наголошують на місиі та ролі оповідань і казок видатного украйнського педагога в процесі виховання морально-етичних якостей дітей. Показано невикористані потениійні можливості художнього спадку педагога-новатора для формування духовного світу школяра за умов сьогодення, його автори справедливо відносять до когорти дитячих письменників. Актуалізовано казки та оповідання, наукові прачі вченого, які вирізняються великою виховною силою: будь-яка казка чи оповідання - ие своєрідна азбука моральності, програма морального виховання й духовного розвитку дитини. Зроблено висновок про широке використання в закладах освіти літературної спадщини В. Сухомлинського.

Ключові слова: казки; оповідання; Василь Сухомлинський; моральне виховання; гуманістична педагогіка; педагог-новатор.

Лim. 13.

Halyna Bilavych, Doctor of Sciences (Pedagogy), Professor of the Pedagogy of Primary Education Department Vasyl Stefanyk Precarpathian NationalUniversity Iryna Didukh, Ph.D.(Pedagogy), Associate Professor, Associate Professor of the Social Pedagogy and Social Work Department,

Vasyl Stefanyk Precarpathian National University Oleh Dovhiy, Ph.D.(Physics and Mathematics), Associate Professor, Associate Professor of the Primary Education Pedagogy Department

Vasyl Stefanyk Precarpathian NationalUniversity Iryna Danyliv, Student of Vasyl Stefanyk Precarpathian NationalUniversity

\section{FAIRY TALES AND SHORT STORIES OF VASYL SUKHOMLYNSKIY AS A FACTOR OF MORAL EDUCATION OF THE CHILD'S PERSONALITY}

$V$. Sukhomlynskiy's multifaceted creative heritage consists of 48 books, 500 scientific articles, more than 1500 fairy tales and short stories. The creative achievement of a humanist teacher is actively republished: only at the beginning of the XXI century, 65 works by V. Sukhomlynskiy were published with a total circulation of over 15 million copies. The works of the scientist have been translated into 59 languages. Important works of V. Sukhomlynskiy include "Spiritual world of a schoolboy", "One hundred tips for a teacher", "Work and moral education", "Parental pedagogy", "Letters to the son", "Book of love", "Pavlyk secondary school", "I give my heart to the children" (published in 1969, translated into 32 languages, contains 55 editions) and others. The problem of education of a comprehensively developed personality plays the leading role in the pedagogical heritage of $V$. Sukhomlinskiy. For the first time in the history of Soviet pedagogy, the scientist substantiated this idea in the form of his concept. This idea was successfully implemented by the teacher-innovator in the work of Pavlyk secondary school.

Among the mental, moral, aesthetic, labor and physical education, the scientist singles out the moral sphere of the personality. $V$. Sukhomlynskiy actualizes the problem of education of moral feelings. In the creative heritage of the outstanding Ukrainian teacher, a great place is occupied by fairy tales and short stories devoted to the moral education of the person. There is a great need for an in-depth analysis of these works of art for children as a factor of learning and moral education of the person. Tales and stories of the director of Pavlyk school are timeless; they are dedicated to the eternal problem of mankind - the preservation of spirituality. $V$. Sukhomlynskiy brings the

(c) Г. Білавич, І. Дідух, О. Довгий,

I. Данилів, 2021 
concept of "morality" to a high (spiritual) level of its understanding, and this gives grounds to claim that the scientist raises moral education of the child to the level of Christian morality, which is based on love to neighbor and good deeds. Works for children are organically interspersed in the thorough works of V. Sukhomlynskiy. For example, it may be seen in the book 'I give my heart to children' (1968, 1969), which has about 40 literary texts, to a slightly lesser extent - in the work "Birth of a citizen" (1970) and others.

Keywords: fairy tales; short stories; Vasyl Sukhomlynskiy; moral education; humanistic pedagogy; teacher-innovator.

П остановка проблеми. Гуманістична педагогіка В. Сухомлинського сьогодні, як ніколи, активно затребувана в житті нової української школи. Біля витоків будь-якого досягнення завжди стоїть учитель, на плечах якого, за твердженням В. Сухомлинського, лежить величезна відповідальність - любити дітей, віддавати їм своє серце, розуміти їхню душу, виховати їх справжніми людьми. За сучасних умов розвитку українського суспільства це завдання $\epsilon$ надскладним. Сьогодні Україна переживає не тільки нестабільність соціально-економічної ситуації, спричиненої, окрім іншого, і перебуванням у стані ведення військових дій на сході держави, трудовою міграцією українців за кордон, що призводить до появи такого явища, як соціальні діти-сироти, соціальної незахищеності багатьох верств населення, наслідками чого, окрім іншого, $\epsilon$ падіння моралі, підміна духовно-моральних орієнтирів, утрата цінностей як у громадському, так і в особистісному сенсі людського життя. У зв'язку з цим моральний компонент визнається значущим і найважливішим чинником буття всіх сфер життєдіяльності соціуму. Проблема виховання моральної відповідальності особистості продиктована й тим, що у XXI ст. висувається теза про зміну “людини розумної" “людиною відповідальною" (С. Капіца); про виховання відповідальної людини зі сформованими громадянськими компетентностями йдеться і в Концепції Нової української школи. Тому важливо виховати юну особистість як відповідальну, чесну, сумлінну людину, що володіє значно більшою, аніж раніше, відповідальністю, здатною самостійно ухвалювати рішення у ситуації вибору, прогнозуючи їх можливі наслідки, діяльну особистість, відповідальну за себе, свою сім'ю, теперішнє і майбутнє України, урешті, майбутнє людства.

Однак сучасна освітня ситуація ускладнюється тим, що самоочевидність моральної відповідальності в шкільному середовищі перестає бути обов'язковою. Багато учнів у своїй діяльності керуються миттєвими бажаннями, а не загальноприйнятими моральними принципами i нормами. На жаль, сучасна сім'я в силу різних причин мало уваги приділяє морально-духовному вихованню дітей. Понад те, уроки християнської моралі сьогодні в початковій школі не $є$ обов'язковими, а інтегровані курси, до прикладу, українська мова і читання, не дають широкої можливості для здійснення повною мірою морального виховання. Література як жанр мистецтва, що здатна формувати духовний світ людини, утрачає свій потенціал. Водночас у творах В. Сухомлинського можна віднайти відповідь на будь-яке запитання, що стосується виховання моральної особистості: учений створив своєрідну абетку моральності, яка може слугувати відправною точкою у вихованні справжньої людини для всіх: учнів, педагогів, батьків тощо. У зв'язку з цим виникає необхідність звернення до історико-педагогічного досвіду, авторської системи морального виховання особистості В. Сухомлинського, яку він успішно апробував упродовж тридцятих років, провідні педагогічні ідеї якого варто актуалізувати за умов сьогодення.

Аналіз останніх досліджень і публікацій. Українська педагогічна думка велике значення надає аналізу творчої спадщини В. Сухомлинського. У науці (педагогічній біографістиці) започатковоно цілий напрям - сухомлиністика (М. Антонець, Л. Березівська, Л. Боднар, В. Давилова, Н. Дічек, Л. Заліток, Г. Ткаченко, О. Петренко, О. Савченко, О. Сухомлинська, М. Ярмаченко та ін.), де спадщина В. Сухомлинського досліджуеться в контексті різних наукових проблем. Велика роль у вивченні творчих надбань видатного українського педагога, популяризації ідей і практичного понад тридцятирічного досвіду Павлиського директора належить фахівцям Державної наукової педагогічної бібліотеки ім. В. О. Сухомлинського, яку очолює членкореспондент НАПН України О. Сухомлинська [6].

Мета статті - проаналізувати творчий потенціал літературної спадщини В. Сухомлинського для дітей та обгрунтувати педагогічні умови реалізації ідей ученого щодо морального виховання учнів початкової школи.

Виклад основного матеріалу. Багатоаспектна творча спадщина В. Сухомлинського становить 48 книг, 500 наукових статей, понад 1500 казок та оповідань. Творчий здобуток педагога-гуманіста активно перевидається: тільки на початку XXI ст. вийшло 65 творів В. Сухомлинського загальним накладом понад 15 млн примірників. Твори вченого перекладено 59 мовами світу, до найгрунтовніших і найвагоміших з яких належать 
КАЗКИ ТА ОПОВІДАННЯ ВАСИЛЯ СУХОМЛИНСЬКОГО ЯК ЧИННИК МОРАЛЬНОГО ВИХОВАННЯ ОСОБИСТОСТІ ДИТИНИ

“Духовний світ школяра”, “Сто порад учителеві”, “Праця і моральне виховання”, “Батьківська педагогіка”, “Листи до сина”, “Книга про любов”, "Павлиська середня школа", “Серце віддаю дітям” (1969 р., видана 32 мовами світу, має 55 видань) та ін. [3].

Художні надбання В. Сухомлинського $є$ помітним складником його великої педагогічної спадщини. В Україні юнацтво, люди середнього віку більше знають В. Сухомлинського саме як дитячого письменника, а не як педагога, позаяк упродовж майже тридцяти років у різних видавництвах часто з'являються художні твори педагога-гуманіста (збірки казок та оповідань), також ці твори є складником навчальної літератури для закладів дошкільної освіти, початкової школи, різних читанок, хрестоматій, книг до читання, тобто твори для дітей стали частиною вітчизняного освітнього простору.

Передовсім наголосимо: оповідання та казки В. Сухомлинського відносимо до категорії літератури для дітей (дитячої літератури) як художні, науково-популярні тексти, створені дорослими та спеціально адресовані дітям, які враховують їхні вікові особливості, розвиток, мають не тільки емоційно-ціннісне забарвлення, а й велику виховну та освітню спрямованість. Позаяк вони невеликі за обсягом, лаконічні (небагатослівні), написані простою й доступною для розуміння мовою, ми відносимо їх до творівпритч, оскільки вони таять у собі глибоку мораль.

Утім, як показали результати контент-аналізу чинних підручників для початкової школи 3 інтегрованого курсу українська мова та читання для НУШ [2; 4; 12], казки та оповідання В. Сухомлинського або не вміщено в навчальних книгах для дітей [2; 12], або вони є в незначній кількості [4]. Отже, величезний моральноетичний, духовний потенціал безсмертних творів

В. Сухомлинського за умов сьогодення абсолютно не використаний.

Твори для дітей органічно вкраплені в грунтовних працях В. Сухомлинського. До прикладу, книга “Серце віддаю дітям” $(1968,1969)$ налічує близько 40 художніх текстів [9], дещо менше - у праці "Народження громадянина" (1970) [8] та ін. Так, у книзі "Народження громадянина" педагог наголошує на своєму авторстві в написанні оповідань та казок: “Я написав хрестоматію “Думки про людину”. Це коротенькі оповідання й казки, які викликають у дітей роздуми про людину, співчуття до іiї горя і нещастя" [8, 34].

Наведена цитата увиразнює виховне та освітнє значення художніх творів для дітей морального змісту, якому педагог-гуманіст надавав першорядного значення у вихованні. А також підкреслює те, що така робота активно велася в Павлиській школі, до літературної творчості учений постійно залучав учнів, разом з педагогом вони створювали різного роду хрестоматії, присвячені важливим проблемам, 3-поміж яких “Думки про людину”, “3 чого починається для мене Батьківщина”, “Твори учнів Павлиської середньої школи 1968-1969 н.р.”, “Хрестоматія моральних цінностей” та ін. [3, 123-125]. У 1960-х рр. розпочинається поширення авторської системи

В. Сухомлинського в ділянці морального виховання, засобами якого виступають казки та оповідання для дітей і про дітей, його починають поціновувати і як дитячого письменника. Знаковою подією, - зазначає науковець Л. Старикова, - для сприйняття В. Сухомлинського як дитячого письменника стала вихід у світ 1990 p. його “Хрестоматия по этике”, до якої ввійшли 542 мініатюри $[3,124]$. Це досі найповніше видання оповідань та казок педагога; його наклад становив 100 тис. примірників.

Одним із найвагоміших і значущим видань упродовж усіх років літературного життя педагогановатора $\epsilon$ книга "Я розповім вам казку. Філософія для дітей” (2016) [11], що відкриває новий етап у розумінні і освоєнні художнього світу, створеного В. Сухомлинським для дітей, - поєднання художніх образів із пізнанням дитиною світу і самої себе, коли педагогіка подається через художні образи, емоційно-ціннісне сприйняття художнього твору і педагогічні приписи об'єднані в один твір. Це найповніше видання художніх мініатюр В. Сухомлинського із нині опублікованих (679 одиниць) [3, 124].

Науковці $[1 ; 3 ; 13]$ справедливо зауважують, що в педагогічній спадщині В. Сухомлинського особливе місце належить літературним творам, адресованим дітям. У жанровому вимірі їх можна розділити на казки, розповіді, нариси. Це невеликі за обсягом тексти, читання яких, самостійне / або з дорослими, займає не більше десяти хвилин. Це читання, яке викликає в серці дитини гарячий емоційний відгук, духовне очищення, спонукає іiі до роздумів, саморефлекії, викликає глибокі духовно-моральні почуття. Твори для дітей В. Сухомлинського варті уваги й переоцінки за умов сьогодення насамперед тому, що в них знайшли бескомпромісне розв'язання важливі моральні питання. По суті, кожна мініатюра Великого Гуманіста XX сторіччя підносить читачеві неоціненний моральний урок. Твори В. Сухомлинського для дітей - це кодекс моралі, настільна книга, яку читати потрібно щодня, це 
КАЗКИ ТА ОПОВІДАННЯ ВАСИЛЯ СУХОМЛИНСЬКОГО ЯК ЧИННИК МОРАЛЬНОГО ВИХОВАННЯ ОСОБИСТОСТІ ДИТИНИ

своєрідні педагогічні заповіді того, як стати Людиною.

У педагогічних працях ученого ці уроки докладно розроблені. Звертаючись до колег і батьків, педагог акцентує їхню увагу на найголовнішому - “святині душі”. Не можна забувати про те, що для педагога була надзвичайно важлива ідея комуністичного виховання школярів, тому для визначення виховної домінанти в спадщині В. Сухомлинського, на нашу думку, правильніше було б використовувати термін “моральне", аніж “духовне”, хоча поняття “духовний”, “духовність”, “душа” незмінно в центрі його уваги. Для нас, людей, що живуть в епоху відродження християнських цінностей у вихованні, це уточнення є істотним.

Учитуючись у рядки казок В. Сухомлинського $[6 ; 11]$, аналізуючи створені ним образи, можна побачити в текстах і щось більш глибоке, дещо таке, що сягає корінням у далеке минуле. Те значення, яке надавав педагог казкам для дітей, також потребує окремого розгляду.

Традиційно в системі української народної педагогіки велике місце посідала казка. Спочатку вона була не зовсім адресована дітям, а слугувала передачі знань про світ і людину прийдешнім поколінням. “Казка - це духовні багатства народної культури, пізнаючи які дитина пізнає серцем рідний народ" [9, 154], - зазначав педагог. Казка завжди знаходила відгук у дитячих серцях. Спитаючись на споконвічний досвід українства, В. Сухомлинський, український філолог за освітою, відроджує ії̈ значення: “Слово казки живе в дитячій свідомості... Я не уявляю собі навчання в школі не тільки без слухання, а й без створення казки... " [9, 154]. Глибокий знавець дитячої психології, В. Сухомлинський зазначав: “Завдяки казці дитина пізнає світ не тільки розумом, але й серцем. I не тільки пізнає, але відгукується на події і явища навколишнього світу, висловлюючи своє ставлення до добра і зла" [9, 154].

У його Павлиській школі була обладнана Кімната казок, де діти себе могли відчути у світі казкових образів. Про що ж казки В. Сухомлинського? Насамперед про людину і іï внутрішній світ. Це правда про людську душу. Це завжди моральний урок. Універсальність проблематики казок, “тяжіння до глибинної премудрості”, алегорична форма й особливий символізм образів дає змогу визначити жанр багатьох літературних творів В. Сухомлинського як казку-притчу [1].

Казки-притчі про красу посідають чільне місце серед усієї літературної спадщини педагога, у творах "Красиве і потворне”, “Хлопчик і дзвіночки конвалій”, “Нехай будуть соловей і жук” та багатьох інших звучить одна надзвичайно важлива думка: краса - не тільки зовнішня досконала оболонка людини, краса має бути в душі людини, вона завжди несе добро. І головне їі призначення - порятунок. Порятунок душі. I, навпаки, "найпотворніше, коли людина стає злою, безсердечною” (“Красиве і потворне”) [6]. Краса у В. Сухомлинського завжди розчинена в природі і має джерело в іiі довершеності й мудрості.

Образ природи в спадщині В. Сухомлинського має надзвичайно глибокий зміст. Природа виступає мудрим учителем-наставником (“Пелюстка і квітка", “Бджола і гарбузова квітка", “Чому голуби прилетіли до Олега”). Природа завжди справедлива (“Зайчик і горобина”, "Крила матері”, “Зозулине горе”) [6]. В образах природи прихована справжня народна мудрість, яка людині відкривається не відразу і не кожному.

У казці “Зозулине горе” письменник пропонує непростий урок тим, хто звик мислити стереотипами, сліпо вірить громадській думці, хто не обтяжує себе увагою до живого почуття. Зозуля ввійшла в культуру і фольклор як образ несумлінної матері, яка покидає своїх дітей. Поіншому радить поглянути на цей стереотип В. Сухомлинський. "Усі вважають мене жорстокою. Лише тільки зазеленіє ліс, вилазить зі своїх лялечок гусінь. Багато з'являється в лісі гусені - великої, волохатої, зеленої, отруйної. Жодні птахи їх не їдять, а я їм. Якби не їла я цих хижаків, загинув би ліс. 3’їла б усе листя гусінь. Коли мені пташенят виводити ... “, - відкриває правду про своє горе нещасна, згорьована за своїми дітьми зозуля [6].

У цій та багатьох інших казках-притчах звучить і найсокровенніша для В. Сухомлинського тема - тема батьківської любові і любові дітей до батьків. “Якби мене запитали, що найважче в нашій роботі, я б відповів: говорити з дитиною про його батька і матір. Тут найменше невміння, помилка, неточність можуть призвести до згубних наслідків”, - писав педагог у своєму “Слові до батьків” [10]. Для розмови на цю важку і надважливу тему педагог-новатор вибрав особливі стиль та мову. "Материнська любов", “Крила матері”, “Легенда про матір”, “Зозулине горе”, “Дві матері”, “Як врятувалася Ластівка" - у цих та інших казках-притчах у реальних і алегоричних образах відтворено образ самовідданої материнської любові, яка уособлює самопожертву, самозречення, глибоке усвідомлення своєї відповідальності за майбутнє. І сильнішої за неї немає сили на світлі. Багато притч про матерів мають драматичний сюжет, звучать трагічно, а тому катарсично впливають на юного читача 
При цьому педагог-письменник порушує проблему зради, цинічного, споживацького ставлення дітей щодо старших. Образ синазрадника виведений, до прикладу, у “Легенді про материнську любов", "Мамині синочки", "Гарному і потворному”, оповіданні “Собаці собача смерть”, “Людина без імені”, цей образ морально огидний і естетично потворний, тому що “немає в цієї людини нічого святого за душею. Не болить їі душа ні за матір, ні за землю рідну” (“Людина без імені”) [6]. Ницістю, боягузтвом, егоїзмом відрізняються вчинки розпещених у дитинстві негативних героїв казок-притч. “Серце його жило тільки своїми радощами, жодне бажання не виходило за рамки власних задоволень. Тому він і виріс безсердечним людиною, байдужим до горя і турбот, тривог $і$ хвилювань інших людей”, - такий діагноз ставить педагог-письменник одному з героїв (“Мамин синочок") [6]. Антигерой у В. Сухомлинського завжди протиставлений відданим родині, батькам, батьківщині дочкам і синам. Моральна чистота - риса, що консолідує цих героїв.

Героямиказок-притч виступаютьуВ. Сухомлинського і люди, і птахи, і тварини, і рослини. Найчастіше це алегоричні образи, замислюючись над якими читач доходить розуміння універсальності і надчасової моральної проблематики.

Висновки і перспективи подальших досліджень. Провідною у педагогічній спадщині В. Сухомлинського є проблема виховання всебічно розвиненої особистості, яку вчений уперше в історії педагогіки радянської доби порушив та глибоко обгрунтував у вигляді розгорнутої авторської концепції, вона знайшла практичне втілення у розвитку та досвіді Павлиської середньої школи. Педагог-новатор серед компонентів цього процесу виокремлює розумове, моральне, естетичне, трудове і фізичне виховання, а системоутворювальним чинником моральну сферу особистості,

В. Сухомлинський актуалізує проблему виховання моральних почуттів. У творчій спадщині видатного українського педагога велике місце посідають праці, присвячені моральному вихованню особистості. $Є$ велика потреба в глибокому аналізі творчого потенціалу творів для дітей як чинника навчання та морального виховання особистості дитини. Їх поціновуємо як дороговказ у формуванні моральних цінностей дітей, юнацтва, дорослих, вони повинні стати моральним кодексом для майбутнього педагога, кожного вчителя, кожного батька та матері. Казки та оповідання Павлиського директора позбавлені прикмет часу, а тому - понадчасові, позаяк звернені до вічної проблеми людства збереження духовності. В основі морального виховання педагог називає турботу / опіку людини про людину, відповідальність людини за людину; виводить поняття "моральність" на високий (духовний) щабель його розуміння, а це дає підстави стверджувати, що моральне виховання вчений підносить на рівень християнської моралі, в основі якої - любов до ближнього, батьків, Батьківщини, добрі справи людини.

Перспективами подальшого дослідження ми вбачаємо в тому, щоб розглядати процес виховання моральних якостей школярів засобами творів для дітей В. Сухомлинського в навчальновиховному середовищі закладу освіти, у тісній співпраці сім'ї, школи, громадськості, церкви; у розробці проблеми морального виховання учнів початкової школи в позашкільних закладах освіти; тощо.

\section{ЛІТЕРАТУРА}

1. Білавич Г. В. “Казки школи під голубим небом" В. Сухомлинського як засіб етикоекологічного виховання. Проблеми дитинства у контексті сучасної педагогіки: зб. наук. праць на пошану Василя Сухомлинського / за ред. М. Чепіль, М. Ярушак. Дрогобич: Редакційно-видавничий відділ Дрогобицького державного педагогічного університету імені Івана Франка, 2018. С. 14-19.

2. Пономарьова К. І., Гайова Л. А.Українська мова та читання: підручник для 3 класу. Частина 1. Київ: Оріон, 2020. 162 с.

3. Старикова Л. В. Оповідання та казки Василя Сухомлинського та їх розповсюдження в Україні і світі. Вісник Житомирського державного університету імені Івана Франка. Педагогічні науки. 2017. Випуск 5(91). С. 122-127.

4. Савченко О. Українська мова та читання: підручник для 3 класу. Частина 2. Київ: Оріон, 2020. 144 c.

5. Сухомлинський Василь Олександрович. URL: http://dnpb.gov.ua/ua.

6. Сухомлинський В. Казки Школи під голубим небом. Київ: Радянська школа, 1991. 178 с.

7. Сухомлинський В. О. Моральні заповіді дитинства і юності. Київ: Рад. шк., 1966. 232 с.

8. Сухомлинський В. О. Народження громадянина. Київ : Рад. шк., 1970. 288 с.

9. Сухомлинський В. О. Серце віддаю дітям. Харків : Акта, 2012. 545 с.

10. Сухомлинський В. О. Слово до батьків. Правда. 1970. 5 січня.

11. Сухомлинський В. О. Я розповім вам про казку... Філософія для дітей. Збірка творів/укл. 


\section{КАЗКИ ТА ОПОВІДАННЯ ВАСИЛЯ СУХОМЛИНСЬКОГО ЯК ЧИННИК МОРАЛЬНОГО ВИХОВАННЯ ОСОБИСТОСТІ ДИТИНИ}

Ольга Сухомлинська. Київ: Видавничий дім “Школа", 2016. 575 с.

12. Хрестоматія сучасної української дитячої літератури в 3, 4 класах серії “Шкільна бібліотека” / укл. Тетяна Стус. Львів: Видавництво Старого Лева, 2016. 192 с.

13. Чепіль М. Ідея добра і любові у педагогічній спадщині Василя Сухомлинського. Молодь $i$ ринок. 2012. № 1. С. 37-41.

\section{REFERENCES}

1. Bilavych, H. V. (2018). "Kazky shkoly pid holubym nebom" V. Sukhomlynskoho yak zasib etyko-ekolohichnoho vykhovannia ["Fairy tales of the school under the blue sky" by V. Sukhomlinsky as a means of ethical and ecological education]. Problems of childhood in the context of modern pedagogy: coll. Science. works in honor of Vasyl Sukhomlynsky. (Ed.). M. Chepil, M. Yarushak. Drohobych. pp. 14-19. [in Ukrainian].

2. Ponomarova, K. I., \& Haiova, L. A. (2020). Ukrainska mova ta chytannia: pidruchnyk dlia 3 klasu [Ukrainian language and reading: a textbook for 3rd grade]. Part 1. Kyiv, 162 p. [in Ukrainian].

3. Starykova, L. V. (2017). Opovidannia ta kazky Vasylia Sukhomlynskoho ta yikh rozpovsiudzhennia v Ukraini i sviti [Stories and tales of Vasyl Sukhomlynsky and their distribution in Ukraine and the world]. Bulletin of Zhytomyr State University named after Ivan Franko. Pedagogical sciences, Vol. 5(91). pp. 122-127. [in Ukrainian].

4. Savchenko, O. (2020). Ukrainska mova ta chytannia: pidruchnyk dlia 3 klasu [Ukrainian language and reading: a textbook for 3rd grade]. Part 2. Kyiv, 144 p. [in Ukrainian].

5. Sukhomlynskyi Vasyl Oleksandrovych (2008). [Sukhomlynskyi Vasyl Oleksandrovych]. Available at: http://dnpb.gov.ua/ua [in Ukrainian].

6. Sukhomlynskyi, V. (1991). Kazky Shkoly pid holubym nebom [Tales of the School under the blue sky]. Kyiv, 178 p. [in Ukrainian].

7. Sukhomlynskyi, V. O. (1966). Moralni zapovidi dytynstva i yunosti [Moral precepts of childhood and adolescence]. Kyiv, 232 p. [in Ukrainian].

8. Sukhomlynskyi, V. O. (1970). Narodzhennia hromadianyna [Birth of a citizen]. Kyiv, 288p. [inUkrainian].

9. Sukhomlynskyi, V. O. (2012). Sertse viddaiu ditiam [I give my heart to children]. Kharkiv, 545 p. [in Ukrainian].

10. Sukhomlynskyi, V. O. (1970). Slovo do batkiv [A word to parents]. Truth. 5 January. [in Ukrainian].

11. Sukhomlynskyi, V. O. (2016). Ya rozpovim vam pro kazku... Filosofiia dlia ditei. Zbirka tvoriv [I will tell you about a fairy tale... Philosophy for children. Collection of works]. (Ed.). O. Sukhomlynska. Kyiv, 575 p. [in Ukrainian].

12. Khrestomatiia suchasnoi ukrainskoi dytiachoi literatury v 3, 4 klasakh serii "Shkilna biblioteka"(2016). [A textbook of modern Ukrainian children's literature in grades 3, 4 of the series "School Library”]. (Ed.). T. Stus. Lviv, 192 p. [in Ukrainian].

13. Chepil, M. (2012). Ideia dobra i liubovi u pedahohichnii spadshchyni Vasylia Sukhomlynskoho [The idea of goodness and love in the pedagogical heritage of Vasyl Sukhomlynsky]. Youth and the market,Vol. 1.pp. 37-41. [in Ukrainian].

Стаття надійшла до редакції 12.05.2021

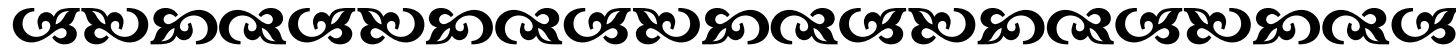

"Не в кількості знань полягає освіта, а в повному розумінні й майстерному застосуванні всього того, що знаєш”.

Адольб Diстервег

німеиький педагог-демоқрат

“Секрет гарного викладання в тому, щоб розглядати інтелект дитини якродюче поле, в яқому можуть бути посіяні насіння щоб вирости в теплі палаючого уяви”.

Марія Монтессорі

італійський педагог, лікар, білособ

"В силу самої своєї природи науқа $і$ логічне мислення ніколи не здатні судити, що можливо, а що - ні. Їх єдине призначення - пояснювати те, що було забікссовано досвідом і спостереженнями". 